\title{
Implementation of Online Learning in Elementary School Students Due To The Covid-19 Pandemic
}

\section{Kharisma Aprilia Ekawati}

SDN Mintobasuki 02

kharismaaprilia580@gmail.com

\section{Article History}

received 3/12/2020

\begin{abstract}
Educators must be able to adapt learning activities to any circumstances. Including in a pandemic situation like this, educators must be able to arrange fun online learning for students. The objectives of this study are (1) to describe the Covid-19 pandemic (2) to describe the concept of online learning (3) the objectives and benefits of online learning (4) the advantages and disadvantages of online learning (5) the barriers to online learning (6) the impact of online learning on students. The results of this study are the implementation of online learning for elementary school students can run well if there is cooperation between teachers, students and parents. Online learning has many challenges and obstacles that can be overcome with good cooperation between teachers and parents, an agreement is established on the learning method to be used. As a professional teacher, you must be able to arrange online learning that is fun and not boring.
\end{abstract}

Keywords: online learning, elementary school, Covid-19

\begin{abstract}
Abstrak
Pendidik harus mampu menyesuaikan kegiatan pembelajaran dengan keadaan apapun. Termasuk dalam keadaan pandemi seperti ini, pendidik harus mampu menyusun pembelajaran daring yang menyenangkan bagi siswa. Tujuan dari penelitian ini adalah(1) Mendeskripsikan pandemi Covid-19 (2) Memaparkan konsep pembelajaran daring (3) Tujuan dan manfaat pembelajaran daring (4) Kelebihan kekurangan pembelajaran daring (5)Hambatan pembelajaran daring (6) Dampak pembelajaran daring bagi siswa. Hasil penelitian ini adalah implementasi pembelajaran daring pada siswa sekolah dasar dapat berjalan dengan baik apabila ada kerjasama anatra guru,siswa dan orang tua. Pembelajaran daring banyak sekali tantangan dan hambatan hal itu bisa diatasi dengan kerjasama yang baik antara guru dan orang tua, terjalin kesepakatan metode pembelajaran yang akan digunakan. Sebagai guru yang profesional harus mampu menyusun pembelajaran daring yang menyenangkan dan tidak membosankan.
\end{abstract}

Kata kunci: pembelajaran daring, sekolah dasar, Covid-19

Social, Humanities, and Education Studies (SHEs): Conference Series https://jurnal.uns.ac.id/shes

p-ISSN 2620-9284 e-ISSN 2620-9292 


\section{PENDAHULUAN}

Pada akhir tahun 2019 Indonesia dihebohkan dengan muculnya virus yang pertama kali berasal dari Wuhan Cina, virus tersebut dinamakan Covid-19. Virus ini sangat cepat menyebar di Indonesia dan beberapa negara di dunia. World Health Organization (WHO) mengumumkan pada tanggal 11 Maret 2020 bahwa Covid-19 dinyatakan sebagai pandemi (Arifah Prima Satrianingrum,2020). Dalam ramgka menekan peningkatan penyebaran Covid-19 pemerintah mengharuskan masyarakat untuk menjaga kesehatan dengan menjaga jarak, selalu memakai masker saat keluar rumah dan rutin menjaga kebersihan tangan dengan cara mencuci kedua tangan menggunakan sabun atau handsanitizer. Selain itu pemerintah juga melarang adanya aktivitas masyarakat yang menimbulkan kerumunan massa

Dengan adanya virus Covid -19 di Indonesia saat ini berdampak bagi seluruh masyarakat. Pada tanggal 24 maret 2020 Menteri Pendidikan dan Kebudayaan Republik Indonesia mengeluarkan Surat Edaran Nomor 4 Tahun 2020 Tentang Pelaksanaan Kebijakan Pendidikan Dalam Masa Darurat Penyebaran COVID, dalam Surat Edaran tersebut dijelaskan bahwa proses belajar dilaksanakan di rumah melalui pembelajaran daring/jarak jauh dilaksanakan untuk memberikan pengalaman belajar yang bermakna bagi siswa. Belajar di rumah dapat difokuskan pada pendidikan kecakapan hidup antara lain mengenai pandemi Covid-19 (Wahyu Aji Fatma Dei, 22020). Pembelajaran yang dilakukan pada siswa sekolah dasar secara daring jarak jauh sangat membutuhkan adanya dampingan dari pihak orang tua.Selain itu pembelajaran daring juga membutuhkan adanya jaringan internet yang stabil. Dengan pembelajaran daring siswa memiliki keleluasaan waktu dalam belajar dan dapat belajar kapapanpun dan dimanapun.Dalam melakukan pembelajran daring siswa dan guru membutuhkan adanya aplikasi yang memudahkan siswa dan guru dalam melakukan interaksi. Beberapa aplikasi yang dapat dimanfaatkan untuk menujang pembelajaran daring seperti classroom, video converence, telepon atau live chat, zoom maupun melalui whatsapp group.

Pada masa pandemi saat ini pembelajaran daring ini tidak hanya pada pendidikan tingkat tinggi dan menengah, tetapi juga pada dilakukan pendidikan tingkat dasar karena adanya pembatasan pada sekolah-sekolah dengan sistem tatap muka. (Marlin kristina,2020). Pembelajaran daring ini masih banyak kendala yang terjadi selama beberapa periode belajar online berlangsung misalnya dari segi keterbatasan guru dalam mengusai pembelajaran online, karena tidak semua guru sudah familier dalam mengoperasikan aplikasi-aplikasi pembelajaran online, ketersedian alat dan perangkat elektronik yang digunakan yang bisa mendukung pembelajaran online berlangsung, ataupun kendala dari segi sinyal dan ketersediaan kuota yang memadai saat pembelajaran online berlangsung, serta permasalahan lainnya yang timbul dari pembelajaran online ini.

Pembelajaran daring ini merupakan inovasi pendidikan untuk menjawab tantangan akan ketersediaan sumber belajar yang variatif. Keberhasilan dari suatu model ataupun media pembelajaran tergantung dari karakteristik peserta didiknya. Sebagai mana yang diungkapkan oleh Nakayama bahwa dari semua literatur dalam elearning mengindikasikan bahwa tidak semua peserta didik akan sukses dalam pembelajaran online. Ini dikarenakan faktor lingkungan belajar dan karakteristik peserta didik. (Nakayama M, dalam Wahyu Aji Fatma Dewi, 2020). Dibutuhkan adanya kesadaran dari peserta didik sendiri dan bimbingn dari orangtua akar pembelajaran daring dapat berjalan dengan baik.

Berdasarkan uraian tersebut, penelitian ini akan mendeskripsikan informasi mengenai Implementasi Pembelajaran Daring Pada Siswa Sekolah Dasar Pada Masa Pandemi Covid- 19. Tujuan dilakukan penelitia ini adalah untuk mengetahui bagaimana Implementasi Pembelajaran Daring Siswa Sekolah Dasar Pada Masa Pandemi Covid19. Sehingga nantinya dapat dilakukan evaluasi dan perbaikan dalam pelaksanaan 
pembelajaran daring, dengan harapan adanya peningkatan motivasi belajar dan hasil belajar siswa.

\section{HASIL DAN PEMBAHASAN}

\section{A. Pandemi Covid-19}

Coronavirus adalah keluarga besar virus yang menyebabkan penyakit mulai dari gejala ringan sampai berat. Ada setidaknya dua jenis coronavirus yang diketahui menyebabkan penyakit yang dapat menimbulkan gejala berat seperti Middle East Respiratory Syndrome (MERS) dan Severe Acute Respiratory Syndrome (SARS). Coronavirus Diseases 2019 (COVID-19) adalah penyakit jenis baru yang belum pernah diidentifikasi sebelumnya pada manusia. Tanda dan gelaja umum infeksi COVID-19 antara lain gejala gangguan pernapasan akut seperti demam, batuk, dan sesak napas. Masa inkubasi rata-rata 56 hari dengan masa inkubasi terpanjang 14 hari. (Yurianto, Ahmad, 2020)

Penyebaran virus corona ini pada awalnya sangat berdampak pada dunia ekonomi yang mulai lesu, tetapi kini dampaknya dirasakan juga oleh dunia pendidikan. Kebijakan yang diambil oleh banyak negara termasuk Indonesia dengan meliburkan seluruh aktivitas pendidikan, membuat pemerintah dan lembaga terkait harus menghadirkan alternatif proses pendidikan bagi peserta didik maupun mahasiswa yang tidak bisa melaksanakan proses pendidikan pada lembaga pendidikan. Aktivitas yang melibatkan kumpulan orang-orang kini mulai dibatasi seperti bersekolah, bekerja, beribadah dan lain sebagainya. Pemerintah sudah mengimbau untuk bekerja, belajar, dan beribadah dari rumah untuk menekan angka pasien yang terpapar Covid-19. Langkah-langkah telah dilakukan oleh pemerintah untuk dapat menyelesaikan kasus luar biasa ini, salah satunya adalah dengan mensosialisasikan gerakan social distancing (Andri Anugrahan, 2020). Konsep ini menjelaskan bahwa untuk dapat mengurangi bahkan memutus mata rantai infeksi Covid-19 seseorang harus menjaga jarak aman dengan manusia lainnya minimal 2 meter, dan tidak melakukan kontak langsung dengan orang lain, menghindari pertemuan massal.

\section{B. Konsep Pembelajaran Daring}

Kondisi pandemi saat ini menuntut pendidik dalam hal ini adalah guru untuk berinovasi menggubah pola pembelajaran tatap muka menjadi pola pembelajaran tanpa tatap muka. Zhafira, Ertika, dan Chairiyaton (2020), menjelaskan bahwa terdapat model pembelajaran lain yang bisa digunakan oleh tenaga pengajar sebagai media penyampaian ilmu pengetahuan, yaitu pembelajaran daring dan pembelajaran campuran (kombinasi dari dua metode pembelajaran yaitu tatap muka dan pembelajaran daring). Metode pembelajaran daring tidak menuntut siswa untuk hadir di kelas. Pembelajaran daring merupakan program penyelenggaraan kelas dalam jaringan untuk menjangkau kelompok target yang masif dan luas (Yusuf Bilfaqih dan $\mathrm{M}$ Nur Qomarudin,2016). Dengan adanya Pamdemi Covid-19 kegiatan belajar mengajar yang semula dilakukan dengan tatap muka di sekolah diahlikan dengan melakukan pebelajaran daring. Untuk pembeljaran daring dilakukan setiap sekolah bebeda-beda karena disesuaikan dengan kemampuan setiap sekolah.

Pembelajaran daring merupakan pembelajaran yang menggunakan jaringan internet dengan aksesbilitas, konektivitas, fleksibilitas, dan kemampuan untuk memunculkan berbagai jenis interaksi pembelajaran. Pada tataran pelaksanaannya pembelajaran daring memerlukan dukungan perangkat-perangkat mobile seperti smartphone atau telepon android, laptop, komputer, tablet, dan iphone yang dapat digunakan untuk mengakses informasi kapan saja dan dimana saja.Belajar daring atau online dapat dilakukan dengan teknologi digital seperti google classroom, rumah belajar, zoom, video converence, telepon atau live chat dan lainnya. Namun yang 
sangat penting adalah adanya pendampingan, pemberian tugas dan pemantauan oleh kepada siswa, sehingga perkembangan siswa dapat terpantau oleh guru

\section{Tujuan dan Manfaat Pembeajaran Daring}

Secara umum, pembelajaran daring bertujuan untuk memberikan layanan pembelajaran bermutu secara efektif dalam pembelajaran bermutu secara dalam jaringan yang bersifat masif serta terbuka untuk menjangkau audiens yang lebih luas serta lebih banyak. Adapun manfaat pembelajaran daring yaitu

1. Meningkatkan kualitas pendidikan dengan efektif menggunakan multimedia dalam pembelajaran.

2. Meningkatkan ketarjangkauan pendidikan yang berkualitas dengan menerapkan pembelajaran daring.

3. Mengurangi biaya penyediaan pendidikan berkualitas dengan menggunakan sumber daya manusia

\section{Kelebihan dan Kekurangan Pembelajaran Daring}

Pembelajaran daring atau berbasis online memang tidak dapat terelakkan pada masa pandemi ini. Namun, para pengelola pembelajaran harus mampu untuk mengatur mekanisme pembelajarannya dengan baik. Sebab bagaimanapun pembelajaran berbasis daring memiliki kelebihan dan kekurangan. Adapun kelebihannya seperti yang tertera berikut ini:

1. Pembelajaran daring memiliki kelebihan dapat digunakan dalam ragam situasi

2. Pembelajaran daring memiliki kelebihan dalam hal efisiensi waktu, tenaga, dan biaya

3. Pembelajaran daring memiliki kelebihan dalam hal ketidakharusan dalam penggunaan seragam tertentu

4. Pembelajaran daring memiliki kelebihan berupa fleksibilitas dalam bentukbentuk strategi, media, dan evaluasi pembelajaran

Namun pembelajaran berbasis daring juga memiliki kekurangan, adapaun itu ialah sebagai berikut:

1. Pembelajaran daring memiliki kekurangan dalam hal pengkhususan kepada fasilitas aplikasi tertentu

2. Pembelajaran daring memiliki kekurangan dalam hal kesepakatan waktu tertentu, walaupun pada dasarnya bebas memilih waktu.

3. Pembelajaran daring memiliki kekurangan berupa ketergangguan dengan sistem jaringan dan sejenisnya (Khamim Zarkasi Putro, M. A. Amri, Nuraisyah Wulandari, Dedek Kurniawan,2020)

\section{E. Hambatan Pembelajaran Daring}

Beberapa hambatan dan kesulitan yang dialami guru dan siswa dalam melakukan pembelajaran daring adalah sebagai berkut:

1. Kesulitan mencari Jringan Internet

2. Tiak semua orang tua bisa mendamping anak belajar dari rumah

3. Tdak semua siswa memiliki fasilitas komunikasi seperti HP dan laptop

4. Banyak sisa yang kesulitan mengoperasikan aplikasi yang dignakan dalam pembelajaran daring

5. HP yang dipakai untuk mengumpul tugas adalah HP milik orang tuanya, maka siswa baru dapat mengumpulkan tugasnya setelah orang tuanya pulang bekerja

6. pemantauan kejujuran siswa dalam mengerjakan evaluasi karena tidak bisa bertatap muka

untuk menghadapi hambatan pada pembelajaran daring, harus ada kerjaama yang baik anatara guru, siswa dan orangtua. Orang tua harus mendampingi siswa dalam pembelaaran. Huru harus menciptakan suasana pembelajaran daring yang menyenangkan. Sehingga siswa tidak bosan dan tertarik mengikuti pembelajaran. 


\section{F. Dampak Pembelajaran Daring Bagi Siswa}

Pelaksanaan pembelajaran daring dirasa belum optimal dalam penyampaian materi pembelajaran kepada murid, karena biasa belajar di kelas secara face-to-face, sekarang penyampaian materi melalui sebuah wadah. Sehingga guru merasa bahwa pembelajaran menjadi tidak bermakna bagi murid. Salah satu faktornya ialah pembelajaran tidak dilakukan dengan tatap muka secara langsung, maka proses pembelajaran lebih difokuskan dalam bentuk penugasan kepada murid. Ditambah dengan kurangnya minat murid, karena melakukan pembelajaran melalui sebuah grup di aplikasi yang dominan berisi teks. Hal tersebut hanya menstimulasi daya visual anak."Apalagi setelah melakukan pembelajaran secara daring, anak-anak lebih banyak bermain handphone setelah pembelajaran" ungkap orang tua yang menceritakan kepada responden G5. Sebuah penelitian terdahulu memaparkan bahwa gaya belajar murid dalam pembelajaran secara daring cenderung lebih visual dan baca tulis yang kuat(Drago,\& Wagner, 2004). Banyaknya platform yang mendukung secara gratis, seperti Google Classroom, Whatsapp, Quipper dan lain sebagainya(Abidah, Hidayaatullaah, Simamora, Fehabutar,\& Mutakinati, 2020)yang dapat mengirimkan pesan teks, gambar, video dan file lain(Kusuma, 2020)namun penggunaan platform tersebut belum efektif, karena keterbatasan sarana prasarana di sebagian murid kurang memadai. Pelaksanaan pembelajaran secara daring terkesan tidak rata dan cenderung teachercentered. Ditambah lagi, jika melakukan sebuah diskusi, ada yang menjadi silence reader dan respon dari murid pun sedikit lebih pendek (Moorhouse, 2020)

\section{SIMPULAN}

Coronavirus adalah keluarga besar virus yang menyebabkan penyakit mulai dari gejala ringan sampai berat. Penyebaran virus corona ini pada awalnya sangat berdampak pada dunia ekonomi yang mulai lesu, tetapi kini dampaknya dirasakan juga oleh dunia pendidikan. Kebijakan yang diambil oleh banyak negara termasuk Indonesia dengan meliburkan seluruh aktivitas pendidikan, membuat pemerintah dan lembaga terkait harus menghadirkan alternatif proses pendidikan bagi peserta didik maupun mahasiswa yang tidak bisa melaksanakan proses pendidikan pada lembaga pendidikan. Aktivitas yang melibatkan kumpulan orang-orang kini mulai dibatasi seperti bersekolah, bekerja, beribadah dan lain sebagainya. Pemerintah sudah mengimbau untuk bekerja, belajar, dan beribadah dari rumah. Untuk menghidari adanya kerumunan di sekolah pemerintah mengaihkan proses pembelajaran yang semula tatap muka menjadi pembelajaran daring. Pembelajaran daring ini merupakan inovasi pendidikan untuk menjawab tantangan akan ketersediaan sumber belajar yang variatif. Pembelajaran daring ini masih banyak kendala yang terjadi selama beberapa periode belajar online berlangsung misalnya dari segi keterbatasan guru dalam mengusai pembelajaran online, karena tidak semua guru sudah familier dalam mengoperasikan aplikasi-aplikasi pembelajaran online, ketersedian alat dan perangkat elektronik yang digunakan yang bisa mendukung pembelajaran online berlangsung, ataupun kendala dari segi sinyal dan ketersediaan kuota yang memadai saat pembelajaran online berlangsung, serta permasalahan lainnya yang timbul dari pembelajaran online ini.

\section{DAFTAR PUSTAKA}

Anugrahana, H., (2020) Hambatan, Solusi dan Harapan: Pembelajaran Daring Selama Masa Pandemi Covid-19 Oleh Guru Sekolah Dasar. Jurnal Pendidikan dan Kebudayaan .10 (3)

Damanik,S., Zuhdi,M.,\&Herlina,,H., Model Evaluasi Pembelajaran Aud Berbasis Daring Di Ra Nurun Namirah Medan Marelan (Studi Kasus Selama Masa Pandemi Covid-19).Jurnal Pendidikan dan Keislaman.3 (1)

Dewi, W.A.F.,(2020) Dampak Covid-19 Terhadap Implementasi Pembelajaran Daring Di Sekolah Dasar. Jurnal IImu Pendidikan.2(1). 
Drago, W. A., \& Wagner, R. G. (2004). Vark preffered learning styles and online education. Management Research News, 27(1)

Kusuma, J. W., \& H. (2020). Platform whatsapp grup dan webinar zoom dalam pembelajaran jarak jauh pada masa pandemik COVID-19. Jurnal IImiah Pendidikan Matematika, 5(1).

Moorhouse, B. L. (2020). Adaptations to face-to-face initial teacher education course "forced" online due to the COVID-19 pandemic. Journal Education for Teaching: International Research and Pedagogy.2(1).

Ramasari,A.F.,Setiawan,F.,\& Faradita, M.N., Pengaruh Pembelajaran Online Terhadap Kemandirian Belajar Siswa Kelas II SD Muhammadiyah 17 Surabaya di Tengah Pandemi Covid-19.Jurnal Guru Pendidikan Sekolah Dasar.4(2).

Satrianingrum, A.P.,\& Prasetyo I.(2021) Persepsi Guru Dampak Pandemi Covid-19 terhadap Pelaksanaan Pembelajaran Daring di PAUD.Jurnal Obsesi.5(1).

Syahruddin, D., (2020)Model Evaluasi Pembelajaran AUD Berbasis Daring di RA Nurun Namirah Medan Marelan. Jurnal Pendidikan dan Keislaman, 3(1)

Yusuf Bilfaqih dan M Nur Qomarudin.(2016). Esensi Pengembangan Pembelajaran Daring: Yogyakarta, Penerbit Deepublish. 